\title{
Effect Of Microwave Radiation On The Retina Of Mice Embryos
}

\author{
Fawzy I. Amer \\ Department of Zoology, Faculty of Science, Ain Shams University
}

Hamza A. El Shabaka

Department of Zoology, Faculty of Science, Ain Shams University

Iman Zakaria

Department of Zoology, Faculty of Science, Ain Shams University

E-mail: zakariaiman@yahoo.co.uk

Hend A. Mohammed

Department of Zoology, Faculty of Science, Ain Shams University

E-mail: Hakm376@yahoo.com

Received: December 19, 2012 Accepted: January 4, 2013

doi:10.5296/jbls.v4i2.2895 URL: http://dx.doi.org/10.5296/jbls.v4i2.2895

\begin{abstract}
The present investigation is concerned with the effect of mobile phone radiation on the development of mice embryos. The pregnant females were divided into 3 groups, the control group (GI) and 2 irradiated groups, 10 females each. The $2^{\text {nd }}$ group and $3^{\text {rd }}$ group were subjected to $950 \mathrm{MHz}$ at $\mathrm{SAR}=1 \mathrm{~W} / \mathrm{kg}$ and $1800 \mathrm{MHz}$ at $\mathrm{SAR}=1.6 \mathrm{~W} / \mathrm{kg}$ respectively from day 7 to day 14 of gestation for 2 hours/ day. The exposure to microwave caused fetal growth retardation in all irradiated groups. However, no morphological abnormalities were observed in all the experimental groups.

The retina of the 18-days-old fetus maternally exposed to microwave showed histopathological changes including pyknotic nuclei in both outer and inner nuclear layers (group II), while they lost their normal arrangement and became aggregated in the outer nuclear layer in group III. At
\end{abstract}


the level of electron microscopy the retinal tissue revealed deformed and dilated mitochondria and condensed heterochromatin of the nuclei of the outer nuclear layer. The ganglionic cells showed degenerated cytoplasmic organelles in group II. However, remarkable aggregations of melanin pigments were detected in the pigmented layer of group III. Since the evaluation of the clinical relevance of microwave radiation interactions on fetal retina is still lacking, such pathological changes must be taken into consideration in order to minimize cell injuries.

Keywords: Retina, Microwave, Teratology, Electromagnetic waves

\section{Introduction}

Electromagnetic radiation consists of waves of electric and magnetic energy moving together through the space. Microwaves are a subset of radiowaves which have frequencies between 3 $\mathrm{kHz}-300 \mathrm{GHz}$. It constitutes part of the whole electromagnetic spectrum. Mobile telephony has developed rapidly over the past ten years. It is now a part of the basic equipment of modern life and over 1.3 billion phones are in use worldwide. The first mobile phone system was analog and used frequencies from 450 and up to $900 \mathrm{MHz}$. Now the digital system, is operated at somewhat higher frequencies (1800-1900 MHz) and it uses different modulating. Over the last few years, concerns about health effects caused by exposure to the microwaves emitted by mobile telephones and base stations have increased as becoming a major societal issue in some countries, or at least among part of the population.

Berman et al. (1981) found no significant differences in the number of alive, dead or total fetuses and in the incidences of external, visceral, or skeletal anomalies between control and experimental fetuses maternally exposed to microwave at power density $28 \mathrm{~mW} / \mathrm{cm}^{2}$ for 100 minutes daily from the $6^{\text {th }}$ day to the $15^{\text {th }}$ day of pregnancy. Nawrot et al. (1981) noted a reduction in fetal weight in CD-1 mice exposed to $30 \mathrm{~mW} / \mathrm{cm}^{2}$ of electromagnetic waves during days 1-6 of gestation. Exposure of pregnant mice to a power density of $30 \mathrm{~mW} / \mathrm{cm}^{2}$ from the $6^{\text {th }}$ day to the $15^{\text {th }}$ day of gestation resulted in a significant increase in the percentage of malformed fetuses, predominantly with cleft palate. Lary et al. (1982) stated that high-intensity 27.12 $\mathrm{MHz}$ radiofrequency (RF) caused a significant incidence of fetal malformations throughout the post implantation period (days7 through 15). It also caused a low but significant incidence of pre-implantation malformations. Fetal weight and crown-rump length were reduced in all post-implantation exposure groups but were not affected by pre-implantation exposure. The incidence of dead or resorbed fetuses was significantly increased in rats irradiated on days 7 or 9 of pregnancy. Marcickiewicz et al. (1986) stated that the pregnant Swiss mice irradiation of 2 hours daily on days 1-8 of gestation with non-thermal intensity $\left(1\right.$ or $\left.10 \mathrm{~mW} / \mathrm{cm}^{2}\right)$ at 2450 $\mathrm{MHz}$ microwave did not lead to resorption or detectable malformations; however, the body mass of 19-day-fetuses was significantly lower than that of the control. On the other hand, the microwave hyperthermia $\left(40 \mathrm{~mW} / \mathrm{cm}^{2}\right)$ at the same conditions led to an increased number of resorptions (about 25\%) compared to control (2\%). O'Conner (1999) stated that the most remarkable observation at intrauterine exposure to radiofrequency (RF) at high exposure was a decrease in fetal mass. Bornhausen and Cheingraber (2000) found that there was no effect on offspring behavior performance of Wister rats maternally exposed continuously during pregnancy to a low-level electromagnetic field $(900 \mathrm{MHz})$ that approximated the highest legal 
exposure of normal population to the radiation of base antennas of the Global System for Mobile (GSM) digital cell-phone. Lahijani and Ghafoori (2000) exposed freshly fertilized chicken eggs to $50 \mathrm{~Hz}$ during the first 24 hours of post laying incubation. All EMF-exposed groups showed an increase in the percentage of developmental anomalies compared to the control. Also, the investigation showed significant differences in the measurements of body weight, length of crown to rump, heart and liver. Grigor'ev (2003) exposed the chicken embryos to electromagnetic field (EMF) from global system for mobile (GSM) during the embryonic development (21 days). The author found that the embryo mortality rate in the incubation period increased to $75 \%$ (versus $16 \%$ in the control group).

Kues et al. (1992) found that pre-treatment of the eyes with ophthalmic drugs increased the sensitivity of the eye to radiofrequency (RF) exposure, so that effects were seen with an average specific absorption rate (SAR) of $2.6 \mathrm{~W} / \mathrm{kg}$. Kues and Monahan (1992) found changes in the cornea, iris and retina of monkeys after exposure to $2.45 \mathrm{GHz}$ pulsed microwaves. Retinal changes were seen at a threshold specific absorption rate (SAR) of $3.9 \mathrm{~W} / \mathrm{kg}$. Sienkiewicz (1997) reported that degenerative changes have been found in various tissues of the eye, including the lens and retina following protracted exposure to pulsed microwave at levels which did not induce significant heating. Kues et al. (1999) exposed rabbits and monkeys to $60 \mathrm{GHz}$ radiation at $10 \mathrm{~mW} / \mathrm{cm}^{2}$. The animals either had one exposure for 8 hours or 4 hours daily for 5 consecutive days. No changes could be seen in the anterior chambers of the animals' eyes as a result of exposure. Ye et al. (2001) concluded that the low power of microwave $10 \mathrm{~mW} / \mathrm{cm}^{2}$ induce ultrastructural changes of rabbit lens epithelial cells such as small cell size, decreased number of mitochondria and balloon- shaped mitochondria. Balik et al. (2005) found that there is no effect on redness of the eyes and vision disturbance, but some statistical evidences are found that mobile phone may cause blurring of vision, secretion, inflammation and lacrimation of the eyes. The results of Balci et al.(2007) suggested that mobile telephone radiation leads to oxidative stress in corneal and lens tissues and that antioxidants such as vitamin C can help to prevent these effects. Vignal et al. (2009) concluded that the studies could not show any significant effect on human eyes when exposed to long-term and low-dose radiation. Zareen et al.(2009) concluded that EMF emitted by a mobile phone caused derangement of chicken embryo retinal differentiation. Demirel et al.(2012) suggested that under a short period of exposure, $3 \mathrm{G}$ mobile phone radiation does not lead to harmful effects on eye tissue and blood in rats.

\section{Materials and Methods}

The present experimental study was carried out on CD-1 mice, with an average body weight of 20 - 30g obtained from the breeding unit of THEODOR BILHARZ RESEARCH INSTITUTE (TBRI), Imbaba, Giza , A.R. Egypt. This animal was selected because of its high fertility rate, short gestation period, genetic stability and its low rate of spontaneous malformations. Virgin females and males were housed separately in wire cages and kept under conditions of regular 12/12 hours light/dark cycles. They were fed on cubes consisting of crude protein, minerals and fibres. Vitamins were added as fresh vegetables and the animals were provided with milk and tap water ad libitum. The assured pregnant females, indicated by the presence of vaginal plug, were divided into 3 groups, including 10 individuals each. The first group (GI) was used as 
control. The individuals of the $2^{\text {nd }}$ and the $3^{\text {rd }}$ groups (GII\&GIII) were exposed to microwaves $950 \mathrm{MHz}$ at specific absorption rate $(\mathrm{SAR}=1 \mathrm{~W} / \mathrm{kg})$ and $1800 \mathrm{MHz}$ at specific absorption rate $(\mathrm{SAR}=1.6 \mathrm{~W} / \mathrm{kg}$ ) (the same as daily human exposure dose) respectively for 2 hours/ day for 8 successive days from day 7 to day 14 of gestation. After 18 days of pregnancy females of both control and experimental groups were sacrificed by cervical dislocation. The uteri were removed, dissected in normal saline solution and the fetuses were taken out for morphological studies. Living fetuses were distinguished from dead ones by their spontaneous movement. The average number of resorption sites as well as the average number and average body weight of fetuses were recorded and statistically analyzed by using Student t-test and ANOVA. The fetuses were carefully examined externally for any morphological malformations in the limbs, digits, head, eyes, ears, jaws, and palate using a binocular microscope. For electron microscopic examination, small pieces of retina of about $1 \mathrm{~mm}^{3}$ were fixed in $2 \%$ cold glutaraldehyde buffered at $\mathrm{pH} 7.2$ with $0.1 \mathrm{M}$ phosphate buffer for 4 hours, then washed in the same buffer solution. The tissues were then washed in distilled water and postfixed in $2 \%$ osmium tetraoxide for 2 hours, then dehydrated in graded ethanol series, cleared in toluene, equal volumes of toluene and epon and finally in pure epon then embedded in an epoxy resin composed of Epon 812 resin. Semithin sections were stained with toluidine blue with $1 \%$ borax and ultrathin sections were stained with uranyl acetate and lead citrate and examined with the electron microscope in the Electron microscope unit of the National Cancer Institute.

\section{Results}

\subsection{Developing Fetuses}

\subsubsection{A-Body Length, Bodyweight, Mortality Rate and Resorption Sites}

The mean body length of the fetuses showed highly significant decrease in group III $(1.76 \pm 0.15)$ as compared with that of the control (2.2 \pm 0.105$)$. Group II also, showed significant decrease of mean body length $(2.01 \pm 0.12)$ as compared with that of the control group (Table1). Members of group II and group III showed highly significant decrease of mean fetal body weight $(0.92 \pm 0.103)$ and $(0.75 \pm 0.11)$ respectively as compared with the control group $(1.14 \pm 0.084)$ (Table2). The total mortality rate was increased in the two experimental groups than in the control. The mortality rate of 18 -days-old fetuses was relatively high $(6.00 \pm 2.96)$ in group III as compared with that of both control $(0.00 \pm 0.00)$ and group II $(2.59 \pm 1.33)$ (Table3). Highly significant increase in the resorption sites was observed in fetuses of group III $(1.0 \pm 1.15)$ as compared with those of both control (GI) group $(0.00 \pm 0.00)$ and experimental group II (0.5 \pm 0.52$)$ (Table4).

Table 1. Showing the effect of microwaves on the body length $(\mathrm{cm})$ of 18-days- old fetuses.

\begin{tabular}{|l|l|l|l|}
\hline & Control & Group II & Group III \\
\hline Number & 10 & 10 & 10 \\
\hline Median & $2.25(2.1-2.4)$ & $1.9(2.1-1.7)$ & $1.75(2-1.5)$ \\
\hline Mean \pm SD & $2.2 \pm 0.105$ & $2.01 \pm 0.12$ & $1.76 \pm 0.15$ \\
\hline
\end{tabular}

P-values comparisons 
Student t-test (significant $\mathrm{P}<0.05$ ).

\begin{tabular}{|l|l|l|}
\hline & Group II & Group III \\
\hline Control & $\mathrm{P}<0.0014^{* *}$ & $\mathrm{P}<0.0001 * * *$ \\
\hline
\end{tabular}

Table 2. Showing the effect of microwaves on the body weight (g) of 18-days- old fetuses.

\begin{tabular}{|l|l|l|l|}
\hline & Control & Group II & Group III \\
\hline Number & 10 & 10 & 10 \\
\hline Median & $1.15(1.3-1)$ & $0.85(1-0.7)$ & $0.75(0.9-0.6)$ \\
\hline Mean \pm SD & $1.14 \pm 0.084$ & $0.92 \pm 0.103$ & $0.75 \pm 0.110$ \\
\hline
\end{tabular}

P-values comparisons

\begin{tabular}{|l|l|l|}
\hline & Group II & Group III \\
\hline Control & $\mathrm{P}<0.0001 * * *$ & $\mathrm{P}<0.0001 * * *$ \\
\hline
\end{tabular}

Student t-test (significant $\mathrm{P}<0.05$ ).

Table 3. Showing the effect of microwaves on the mean percentage of dead embryos (mortality rate) of 18-days- old fetuses.

\begin{tabular}{|l|l|l|l|}
\hline & Control & Group II & Group III \\
\hline Number & 10 & 10 & 10 \\
\hline Mean \pm SD & $0.00 \pm 0.00$ & $2.95 \pm 1.33$ & $6.009 \pm 2.96$ \\
\hline
\end{tabular}

Anova test

$P$ value 0.094 Ins (significant $\mathrm{P}<0.05$ ).

Table 4. Showing the effect of microwaves on the number of resorption sites in control and exposed group.

\begin{tabular}{|l|l|l|l|}
\hline & Control & Group II & Group III \\
\hline Number & 10 & 10 & 10 \\
\hline Mean \pm SD & $0.00 \pm 0.00$ & $0.50 \pm 0.52$ & $1.00 \pm 1.15$ \\
\hline
\end{tabular}

Anova test

$\mathrm{P}$ value $0.0183^{*}$ (significant $\mathrm{P}<0.05$ ).

\subsubsection{B-Incidence of Malformations}

In the present study, fetuses maternally exposed to microwave (groups II and III) did not show any external morphological malformations. However, all the embryos maternally exposed to microwave appeared smaller in size as compared with the control (Fig.A). 


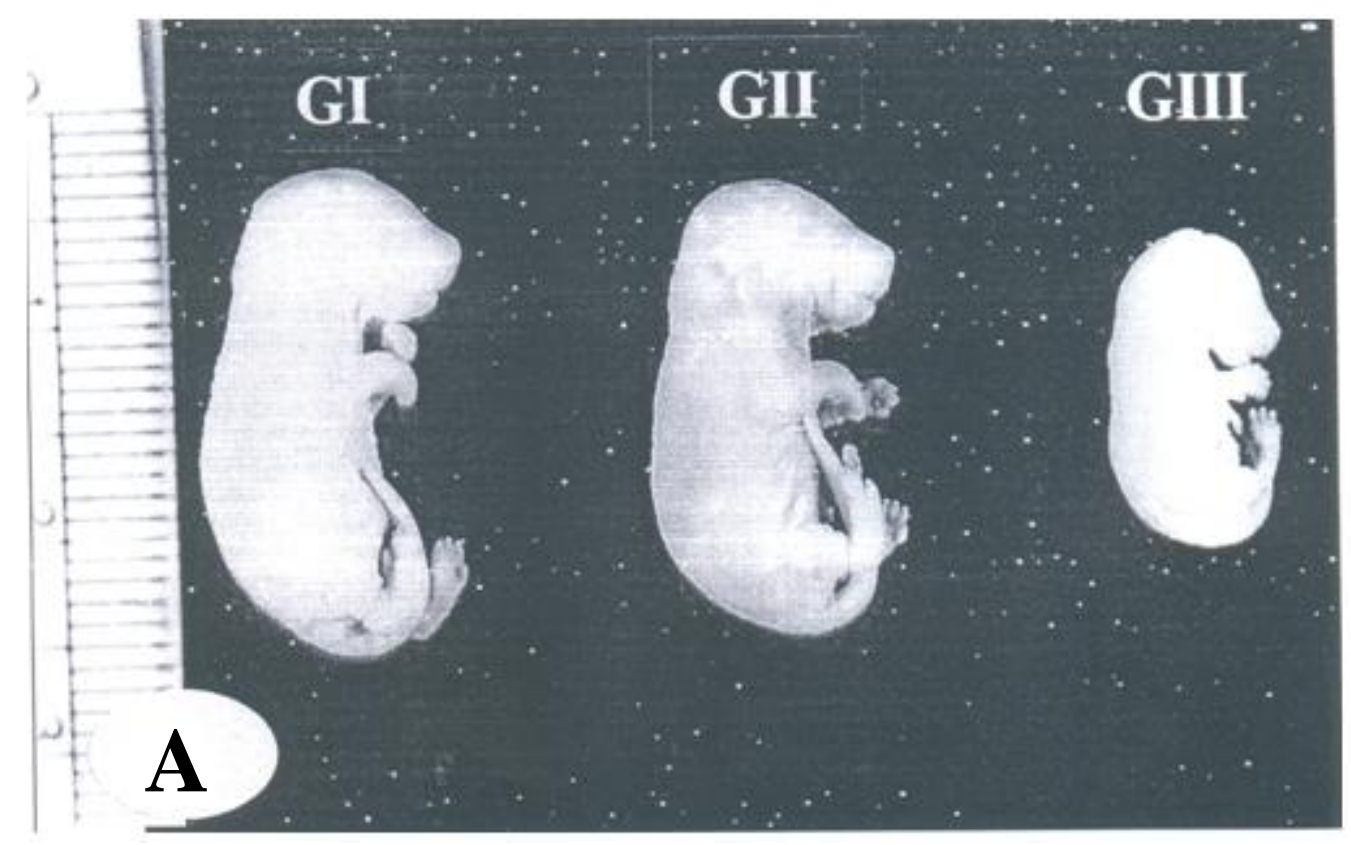

Figure. A. Photomicrograph of 18-days-old fetuses of different groups showing the effect of microwaves on growth.

\subsection{C-The Control Fetus}

\subsubsection{A-Light Microscopic Examination of the Retina}

The retina, the innermost layer of the eye of 18-days-old fetus, is divided into eight layers and comprises four types of cells; pigmented epithelial cells, photoreceptor cells, bipolar cells and ganglionic neurons (Fig.1a). The first layer, or the pigmented layer, consists of polygonal cells arranged in a single layer. The second layer, or the photoreceptor layer consists of rods and cones. The outer segments of photoreceptor cells are still undifferentiated, so the photoreceptor layer of rods and cones is markedly thin. The third layer is called the outer nuclear layer which is composed of the nuclei and cell bodies of photoreceptor cells. The outer plexiform layer which represents the $4^{\text {th }}$ layer of retina is composed of a discontinues irregular layer. In this layer, the synaptic bases of photoreceptors form synaptic junctions with dendrites of bipolar and horizontal cells. The fifth layer is called the inner nuclear layer and is composed of bipolar neurons and supporting Muller cells. The $6^{\text {th }}$ layer represents the inner plexiform layer which is a thin layer. The axons of bipolar cells pass into this layer where they form synapse with the dendrites of ganglion cells. The $7^{\text {th }}$ layer is the ganglion cells layer. The axons of ganglion cells course in the nerve fibre layer, the $8^{\text {th }}$ layer, in which all axons converge to form the optic nerve (Fig.1a).

\subsubsection{B- Ultrastructural Examination of the Retina}

The pigmented layer consists of a single layer of melanin-containing polygonal cells. The cytoplasm of pigment cell is characterized by the presence of numerous pigment granules, mitochondria and lysosomes (Fig.1b). The outer segments of photoreceptor cells are poorly developed while the inner segments are characterized by the presence of remarkable 


\section{Ml Macrothink}

Journal of Biology and Life Science ISSN 2157-6076 2013, Vol. 4, No. 2

aggregations of mitochondria (Figs.1b\&1c). The inner segments of photoreceptor cells contain cilia each of which is composed of fine microtubules (Fig.1d). The outer nuclear layer consists of the nuclei and cell bodies of the photoreceptor cells. The nuclei of rods are densely stained where the heterochromatin forms dense clumps adjacent to the nuclear membrane. However, the nuclei of cones appear faintly stained and contain less amount of heterochromatin (Fig.1e). The oval-shaped bipolar cells of the inner nuclear layer are connected with the synaptic bases of the photoreceptor cells and transmit signals to the ganglion cells. The bipolar cells are characterized by large nuclei and narrow cytoplasm (Fig.1f). The Muller cells (Fig.1f) are tall retinal supporting cells. They extend from the base of the inner segments of the photoreceptor cells up to the retinal surface. The cytoplasm of these cells show pronounced endoplasmic reticulum, glycogen particles and mitochondria. The ganglionic cells (Fig.1g) possess euchromatic nuclei and their cytoplasm contain rough endoplasmic reticulum, mitochondria and few lysosomes (Fig.1h).
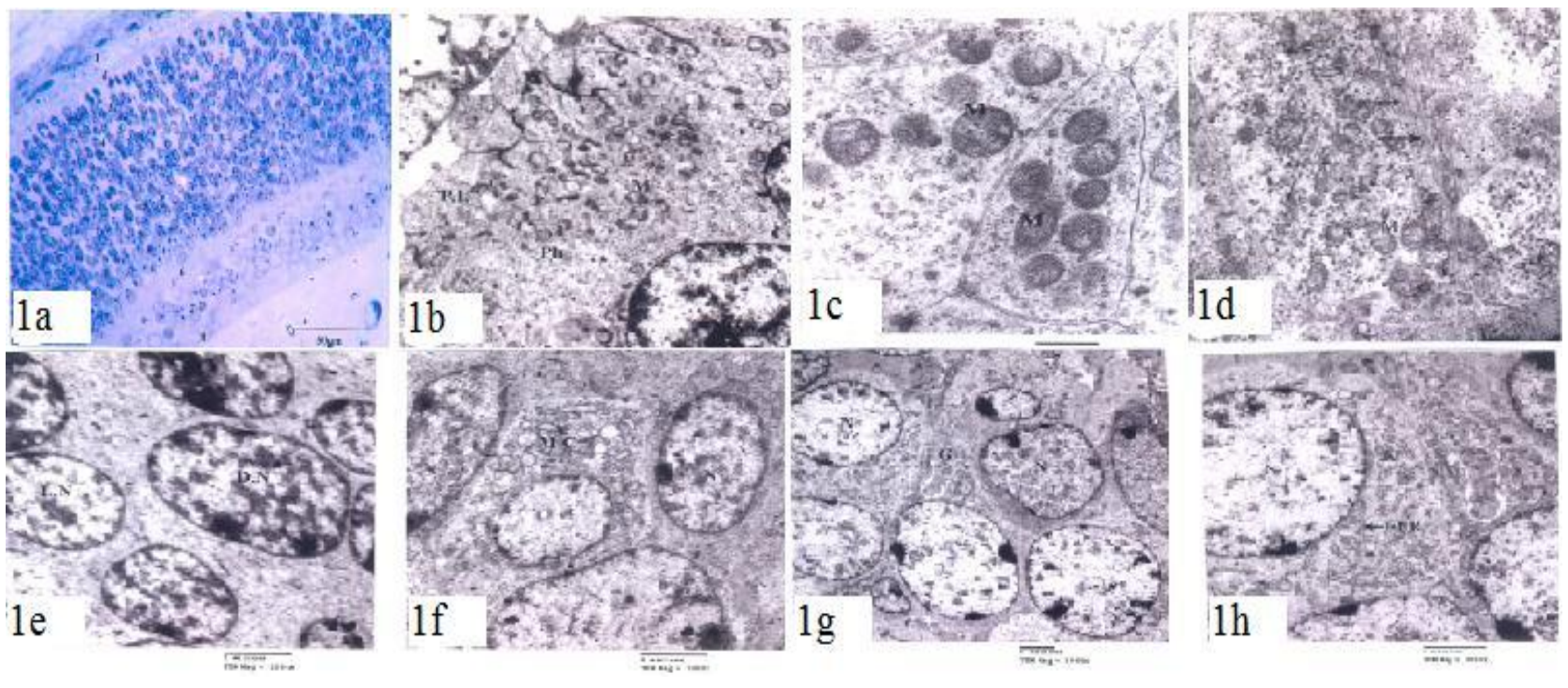

Figure 1a. Semithin section of the eye retina of 18-days-old control fetus showing the eight retinal layers; (1) pigmented layer, (2) photoreceptor cell layer, (3) outer nuclear layer, (4) outer plexiform layer, (5) inner nuclear layer, (6) inner plexiform layer, (7) ganglion cells layer and (8) nerve fibre layer. T.B. stain.

Figure 1b. Electron micrograph of a section of the eye retina of 18-days-old control fetus showing the pigmented layer (P.L) in which the cells contain small granules of melanin pigments (arrow). The inner segments of photoreceptor cells (Ph) contain numerous mitochondria (M).

Figure 1c. Electron micrograph of a section of the eye retina of 18- days-old control fetus showing the inner segments of the photoreceptor cells which contain numerous mitochondria (M).

Figure 1d. Electron micrograph of a section of the eye retina of 18-days-old control fetus showing the microtubules of cilia (arrows) which connect the inner segment of photoreceptor cells to the future outer segments of photoreceptor cells. 


\section{Macrothink}

Journal of Biology and Life Science

ISSN 2157-6076

2013, Vol. 4, No. 2

Figure 1e. Electron micrograph of a section of the eye retina of 18-days-old control fetus showing the outer nuclear layer consisting of electron dense (D.N) and electron- lucent (L.N) nuclei.

Figure 1f. Electron micrograph of a section of the eye retina of 18- days-old control fetus showing the bipolar cells of the inner nuclear layer containing oval nuclei $(\mathrm{N})$ and Mullar cell (M).

Figure 1g. Electron micrograph of a section of the eye retina of 18- days-old control fetus showing a group of ganglion cells $(\mathrm{G})$ possessing euchromatic nuclei $(\mathrm{N})$.

Figure 1h. Highly magnified electron micrograph of ganglionic cell showing euchromatic nucleus $(\mathrm{N})$, mitochondria $(\mathrm{M})$ and rough endoplasmic reticulum (RER).

\subsection{D-Fetuses Maternally Exposed to 950MHz Microwaves and SAR=1 W/Kg (GroupII)}

\subsubsection{A- Light Microscopic Examination}

The semithin sections of the eye retina of 18-days-old fetuses maternally exposed to $950 \mathrm{MHz}$ microwave from day 7 to day 14 of gestation (GroupII) revealed mild histopathological changes in the retinal tissue including pyknotic nuclei in some cells scattered in both the outer and inner nuclear layers.(Fig.2a).

\subsubsection{B- Ultrastructural Examination}

The ultrastructural examination of the retinal tissue of 18-days-old fetuses maternally exposed to $950 \mathrm{MHz}$ microwaves (GroupII) showed that the inner segments of photoreceptors exhibit lipid droplets and deformation of mitochondria which lost their cristae, and became vacuolated (Fig.2b).

The outer nuclear layer of retina shows moderate vacuolation (Fig.2c). The nuclei of electron -dense cells show condensation of heterochromatin.

In the inner nuclear layer some cells possess disintegrated nuclear membrane and numerous heterochromatin and abundant free ribosomes are detected in such cells (Fig.2d).Moreover, numerous vacuoles are seen in the cytoplasm of the inner nuclear cells (Fig.2e).

The ganglionic cells show degenerated cytoplasmic organelles, where the mitochondria appear swollen, with fragmented cristae and severely ruptured inner membrane and marked dilation of the endoplasmic reticula (Fig.2f) 


\section{MInstitute ${ }^{\text {Mim }}$}
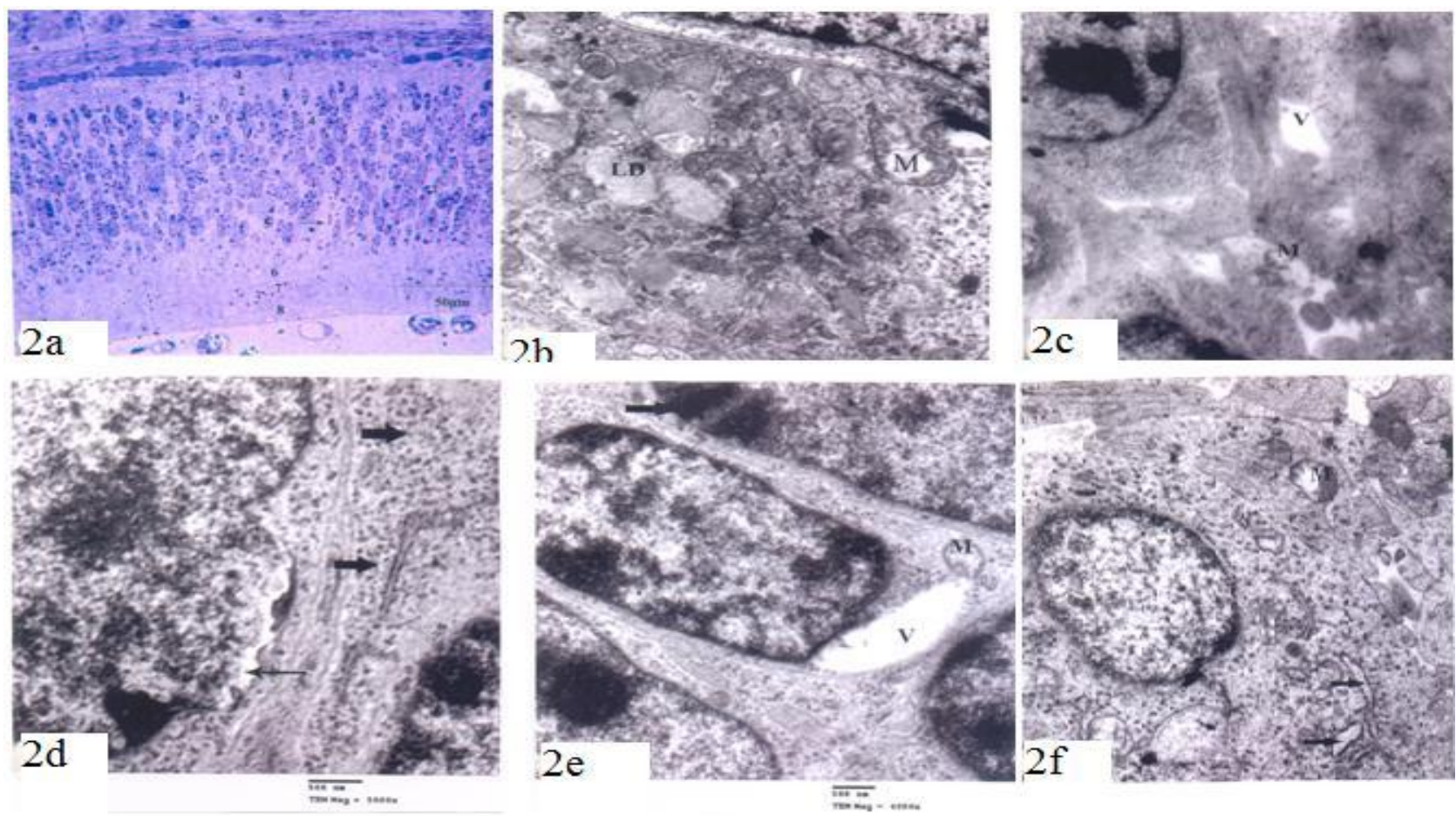

Figure 2a.Photomicrograph of a semithin section of the eye retina of 18-days-old fetus maternally exposed to $950 \mathrm{MHz}$ of microwave (Group II) showing eight layers of the retina (1-8) and some cells showing pyknotic nuclei (arrows). T.B. stain.

Figure $2 b$. Electron micrograph of a section of the eye retina of 18-days- old fetus maternally exposed to $950 \mathrm{MHz}$ of microwave (Group II) showing inner segments of photoreceptor cells containing lipid droplets (LD) and vacuolated mitochondria (M).

Figure 2c. Electron micrograph of a section of the eye retina of 18-days- old fetus maternally exposed to $950 \mathrm{MHz}$ of microwave (Group II) showing outer nuclear layer containing numerous vacuoles $(\mathrm{V})$. The mitochondria $(\mathrm{M})$ are damaged and lost their cristae.

Figure 2d. Electron micrograph of inner nuclear layer of the eye retina of 18-days-old fetus maternally exposed to $950 \mathrm{MHz}$ of microwave (Group II) showing disintegration of the nuclear membrane of the bipolar cell (arrow) and the numerous free ribosomes in the cytoplasm (thick arrows).

Figure 2e. Electron micrograph of a section of the eye retina of 18-days- old fetus maternally exposed to $950 \mathrm{MHz}$ of microwave (Group II) showing inner nuclear area with vacuolated cytoplasm (V), and condensed heterochromatin (arrows).

Figure 2f. Electron micrograph of a section of the eye retina of 18-days- old fetus maternally exposed to $950 \mathrm{MHz}$ of microwave (Group II) showing ganglionic layer with dilated rough endoplasmic reticulum (arrows), the mitochondria (M) with fragmented cristae and severely ruptured inner membrane.

3.4 E-Fetuses Maternally Exposed To 1800MHzMicrowaves and SAR=1.6W/Kg (Group III) 


\section{Macrothink

\subsubsection{A-Light Microscopic Examination}

The examination of the retinal tissue of 18-days-old fetuses maternally exposed to $1800 \mathrm{MHz}$ microwaves from day 7 to day 14 of gestation (GroupIII) shows that the cells lost their normal arrangement and became aggregated in the outer and inner nuclear layers. Some cells in the different layers, specially in the outer and inner nuclear layers as well as in the ganglionic cell layer, show signs of pyknosis where the nuclei appear darkly stained and show high degree of shrinkage (Fig.3a).

\subsubsection{B- Ultrastructural Examination}

The retinal tissue of 18-days-old fetuses maternally exposed to $1800 \mathrm{MHz}$ microwaves from day 7 to day 14 of gestation (GroupIII) shows remarkable aggregation of melanin pigments of different sizes in the pigmented layer (Fig.3b). Moreover, the mitochondria of the inner segments of photoreceptor cells are severely affected; they show large swelling, disorder and destruction of their cristae (Figs.3b-3d). In addition, numerous lipid droplets are also detected in the inner segment of photoreceptors (Fig.3c).

The cell bodies of the photoreceptor cells in the outer nuclear layer show karyolysis of their nuclei (Fig.3e).

Obviously, the bipolar cells of the inner nuclear layer are severely affected. The mitochondria of bipolar cells of the inner nuclear layer have lost their cristae and appeared as empty structures (Figs.3f-3h). Some nuclei of these cells became condensed and deformed (Fig.3h). However, other nuclei appeared normal but, their cytoplasm was vacuolated (Fig.3f). Deformed cytoplasmic organelles in the Mullar's cell were observed where the mitochondria were swollen, damaged and lost their cristae (Fig.3g).

The most striking pathological lesions in the ganglionic layer of this group are the extensive vacuolation of cytoplasm, damaged mitochondria and condensed heterochromatin (Fig.3i). 


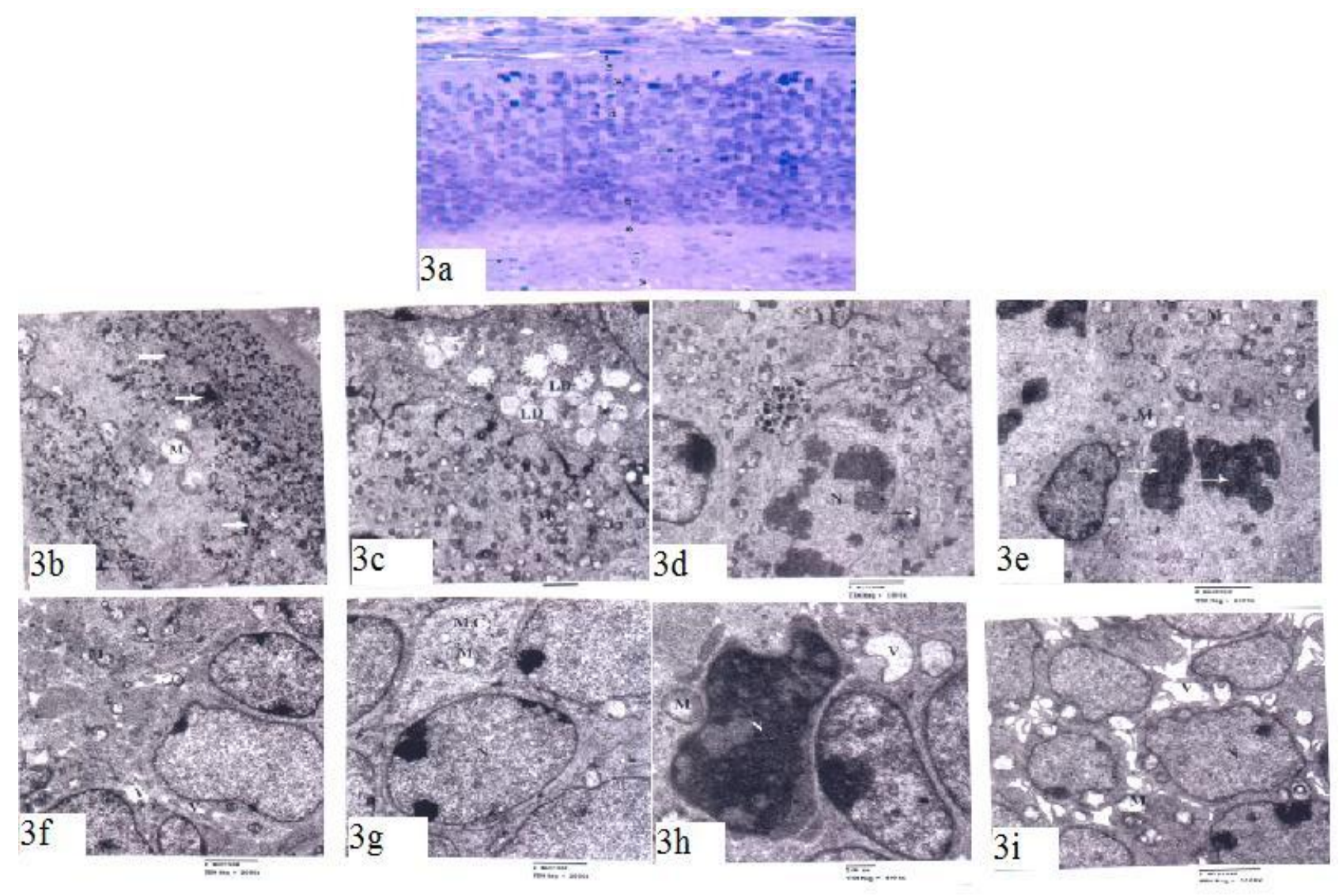

Figure 3a. Photomicrograph of a semithin section of the eye retina of 18-days-old fetus maternally exposed to $1800 \mathrm{MHz}$ of microwave (Group III) showing eight layers of the retina (1-8) with deformed cells and pyknotic nuclei (arrows). T.B. stain.

Figure $3 b$. Electron micrograph of a section of the eye retina of 18-days- old fetus maternally exposed to $1800 \mathrm{MHz}$ of microwave (Group III) showing pigmented epithelial layer containing numerous melanin pigments of different sizes (arrows) and swollen damaged mitochondria (M).

Figure 3c. Electron micrograph of a section of the eye retina of 18-days- old fetus maternally exposed to $1800 \mathrm{MHz}$ of microwave (Group III) showing the inner segments of photoreceptors containing numerous lipid droplets (LD) and swollen, degenerated mitochondria (M).

Figure 3d. Electron micrograph of a section of the eye retina of 18-days- old fetus maternally exposed to $1800 \mathrm{MHz}$ of microwave (Group III) showing that the inner segments of photoreceptors contain deformed mitochondria (arrows) and the nuclei of the outer nuclear layer with condensation of heterochromatin $(\mathrm{N})$.

Figure 3e. Electron micrograph of a section of the eye retina of 18-days- old fetus maternally exposed to $1800 \mathrm{MHz}$ of microwave (Group III) showing degenerated mitochondria (M) aggregated in the inner segment of photoreceptor layer. The outer nuclear layer with fragmented and hyperchromatic nuclei (arrows).

Figure 3f. Electron micrograph of a section of the eye retina of 18-days- old fetus maternally 
exposed to $1800 \mathrm{MHz}$ of microwave (Group III) showing the inner nuclear layer with vacuolated cytoplasm (V) and degenerated mitochondria (M).

Figure $3 \mathrm{~g}$. Electron micrograph of a section of the eye retina of 18-days- old fetus maternally exposed to $1800 \mathrm{MHz}$ of microwave (Group III) showing the Muller cell (MC) in the inner nuclear layer containing mitochondria $(\mathrm{M})$ with deterioration of the cristae, thus most of these mitochondria appear as empty vacuoles.

Figure 3 h. Electron micrograph of a section of the eye retina of 18-days- old fetus maternally exposed to $1800 \mathrm{MHz}$ of microwave (Group III) showing the bipolar cells of the inner nuclear layer with condensed and deformed nucleus $(\mathrm{N})$, damaged mitochondria $(\mathrm{M})$ and vacuolated cytoplasm (V).

Figure 3i. Electron micrograph of a section of the eye retina of 18-days- old fetus maternally exposed to $1800 \mathrm{MHz}$ of microwave (Group III) showing the ganglionic cells with large vacuoles in their cytoplasm (V) and severely degenerated mitochondria (M).

\section{Discussion}

\subsection{Morphological Studies}

In the present study, the average body weight and body length of the fetuses of all groups exposed to microwave showed significant decrease compared with those of the control group. The observed decrease in the mean body weight and mean body length of the developing embryos maternally exposed to microwave is probably due to impairment of blood flow to the placenta and reduced uterine blood flow by the effect of microwaves thus leading to reduced transport of nutrients and oxygen to the fetal circulation. This hypothesis agrees with Nakamura et al. (2003) who found a greater decrease in uteroplacental blood flow in pregnant rats following $915 \mathrm{MHz}$ microwave exposure at $0.6 \mathrm{~mW} / \mathrm{cm}^{2}$, which might result in abnormal pregnancy outcome, including abortion. Also, Braune et al (2002) reported that exposure to $900 \mathrm{MHz}$ using a mobile phone for 2 minutes cause increase of about $5 \mathrm{mmHg}$ in blood pressure during the course of radiation.

The effect of microwave on the fetal body weight, body length, mortality rate and resorption sites was reported in several previous investigations. Nawrot et al. (1981), Berman et al. (1982), Lary et al. (1982), Chazan et al. (1983), Jensh (1984), Marcickiewicz et al. (1986) and Lahijani and Ghafoori (2000).

Chazan et al. (1983) attributed the increased incidence of intrafetal bleeding, resorptions and death of fetuses to the thermal effect of the microwave $\left(40 \mathrm{~mW} / \mathrm{cm}^{2}\right)$. The explanation for this observation is that the absorption of microwave energy leads to the marked elevation of intrauterine temperature and this in turn injures directly the embryonic and fetal cells and tissues.O'Conner (1999) reported that exposure to radiofrequency (RF) at high level caused a decrease in fetal mass.

Lahijani and Ghafoori (2000), showed significant differences in the measurement of body weight of chick embryos exposed to $50 \mathrm{~Hz}$ during the first 24 hours of incubation. Grigor'ev (2003) found an increase in mortility rate in chick embryos exposed to mobile phone. 
On the other hand, no significant alterations in fetal development was observed when Inouye $e t$ al. (1982) exposed pregnant female mice to $2.45 \mathrm{GHz}$ at power densities $9 \mathrm{~mW} / \mathrm{cm}^{2}$ and 19 $\mathrm{mW} / \mathrm{cm}^{2}$. Jensh et al. (1983) exposed pregnant rats to $20 \mathrm{~mW} / \mathrm{cm}^{2}$ at frequency $2450 \mathrm{MHz}$ and Lary et al. (1983) exposed pregnant rats to $100 \mathrm{MHz}$ and power density of $25 \mathrm{~mW} / \mathrm{cm}^{2}$ and they observed no significant alterations in fetal development.

In the present study, fetuses maternally exposed to microwave (groups II and III) did not show any external morphological malformations. This agrees with Chernovetz et al. (1975) who observed no significant differences between the RF and sham groups in the percentages of normal and abnormal fetuses. Also, with Berman et al. (1981) who reported that there was no effect on the developing fetuses exposed to $2450 \mathrm{MHz}$ of microwave at power denisity $28 \mathrm{~mW} / \mathrm{cm}^{2}$ for 100 minute daily from day 6 to day 15 of pregnancy.

On the other hand, Lary et al. (1982) observed increase in fetal malformation and increase in resorbed fetuses in rats exposed to $27.12 \mathrm{MHz}$ radiofrequency on days 7 or 9 of pregnancy.

\subsection{Histological and Ultrastructrual Studies}

The nuclei of photoreceptors of eye retina 18-days-old control fetuses are differentiated into two types; electron-dense nuclei which represent the majority and electron-lucent nuclei. According to Edward et al. (1997) and Lindsay et al. (2004), the electron-dense nuclei which represent the majority are the nuclei of cones, while the electron-lucent nuclei represent the nuclei of rods. These authors reported that cone photoreceptors developed first in the vertebrate retina, followed by rod photoreceptors. Moreover, the outer plexiform layer is a thin layer in which synapse between axons of photoreceptors and dendritic processes of bipolar cells takes place .Since rods and cones of 18 days-old fetuses were not completely differentiated and their axons were not fully grown, thus the outer plexiform layer appeared very thin.

The light microscopic examination of the eye retina of the present work showed pyknotic nuclei in both outer and inner nuclear layers (group II) and deformed nuclei and loss of aggregation in the outer nuclear layer in group III.

At the level of electron microscopy the retinal tissue revealed deformed and dilated mitochondria, mild vacuolation and the nuclei of outer nuclear layer showed condensation of heterochromatin (group II). Also, the retinal tissue of group III showed deformed and swollen mitochondria and vacuolation in the cytoplasm of outer and inner nuclear layers. The cytoplasmic vacuolation and severe degeneration of some organelles of ganglionic neurons were seen. The numerous lipid droplets observed in the outer nuclear layer of the present work, could be attributed to impaired protein synthesis as a result of rough endoplasmic reticulum damage. The changes in the retinal tissue may be attributed to thermal action of the electromagnetic irradiation. Hyland (2000) reported that eyes are one of the most thermally vulnerable area of the body because of their low blood supply. Exposure to high density microwaves can cause detrimental effects on the eye and induce significant biological changes through thermal actions (Nakamura et al., 2003).

Hirata et al. $(2000,2002)$ showed that $5 \mathrm{~mW} / \mathrm{cm}^{2}$ for $1.5-100 \mathrm{GHz}$ caused a temperature change in the lens less than $0.3^{\circ} \mathrm{C}$ at frequencies from 0.6 to $6 \mathrm{GHz}$. This small temperature change is 
overestimated because the eye is thermally isolated from the head and does not incorporate blood flow. In addition, it does not have the same degree of bony protection as the brain which is protected by the skull. Kues and Monahan (1992) found retinal changes in eyes of monkeys at specific absorption rate $(\mathrm{SAR})$ of $3.9 \mathrm{~W} / \mathrm{kg}$.

Sienkiewicz (1997) found abnormal changes of the eye lens. Also, Dovrat et al. (2005) found bubbles of eye lens of 1 -year-old male calves after exposure to $1.1 \mathrm{GHz}$ for up to 8 days.

Aurell and Tengroth (1973) observed retinal lesions and lens opacities in 68 workers who tested and measured radar/microwave fields.

Zusman et al. (1990) found delay in eye opening in rats exposed to $20,50,100 \mathrm{~Hz}$ throughout gestation period. However, Kues et al. (1999) found no changes in the anterior chambers of rabbits and monkeys eyes as a result of exposure to $60 \mathrm{GHz}$ at $10 \mathrm{~mW} / \mathrm{cm}^{2}$ of radiowaves.

The electron microscopic examination revealed degenerative retinal changes in rabbits exposed to pulsed $3100 \mathrm{MHz}$ at 30W/kg (Paulsson et al.,1979). Moreover, Ye et al. (2001) concluded that low power microwave $10 \mathrm{~mW} / \mathrm{cm}^{2}$ induce ultrastructural changes of rabbit lens epithelial cells such as small cell size and balloon-shaped mitochondria. On the other hand, Kamimura et al. (1994) found no corneal effects as well as no effects on the lens and retina in the eyes of monkys exposed to $2450 \mathrm{MHz}$.

No published papers concerning the effect of mobile phone on fetal eye retina are available. So, these results should be further investigated. Since the evaluation of the clinical relevance of microwave radiation interactions on fetal retina is still lacking, such pathological changes must be taken into consideration in order to minimize cell injuries.

\section{References}

Aurell, E. \& Tengroth, B. (1973). Lenticular and retinal changes secondary to microwave $\begin{array}{llll}\text { exposure. } & \text { Optar } & \text { Ophthalmogica, } & \text { 764-771. }\end{array}$ http://dx.doi.org/10.1111/j.1755-3768.1973.tb06045.x

Balci, M., Devrim, E., \& Durak, I. (2007). Effects of mobile phones on oxidant/antioxidant balance in cornea and lens of rats. Curr. Eye Res. Jan, 32(1), 21-5.

Balik, H. H., Turgut- Balik, D., Balikci, K. \& Ozcan, I. C. (2005). Some ocular symptoms and sensations experienced by long term users of mobile phone. Pathol. Biol. ( Paris ), 53(2), 88-91. http://dx.doi.org/10.1016/j.patbio.2004.03.012

Berman, E., Carter, H. B. \& House, D. (1981). Observations of rat fetuses after irradiation with 2450-MHz (cw) microwave. J. Microw. Power, 16 (1), 9-13.

Berman, E., Carter, H. B. \& House, D. (1982). Observations of Syrian hamster fetuses after exposure to 2450-MHz microwaves. J. Microw. Power, 17(2), 107-112.

Bornhausen, M. S. \& Cheingraber, H. (2000). Prenatal exposure to $900 \mathrm{MHz}$, cell-phone electromagnetic fields had no effect on operant-behavior performances of adult rats. Bioelectromagnetics,

21(8),

566-574. 
http://dx.doi.org/10.1002/1521-186X(200012)21:8<566::AID-BEM2>3.0.CO;2-G

Braune, S., Riedel, A., Sculte-Monting, J. \& Raczek, J. (2002). Influnce of a radiofrequency electromagnetic field on cardiovascular and hormonal parameters of the autonomic nervous system in healthy individuals. Radiat. Res., 158(3), 352-356. http://dx.doi.org/10.1667/0033-7587(2002)158[0352:IOAREF]2.0.CO;2

Chazan, B., Janiak, M., Kobus, M., Marcickiewicz, J., Troszynski, M. \& Szmigielski, S. (1983). Effect of microwave exposure in utero on embryonal, fetal and postnatal development of mice. Biol. Neonate., 44(6), 339-348. http://dx.doi.org/10.1159/000241749

Chernovetz, M. E., Justesen, D. R., King, N. W. \& Wagner, J. E. (1975). Teratology, survival, and reversal learning after irradiation of mice by $2450 \mathrm{MHz}$ microwave energy. J. Microw. Power, 10: 391-409. Demirel, S., Doganay, S., Turkoz, Y., Dogan, Z.,Turan, B., Firat, PG.(2012), Effects of third generation mobile phone-emitted electromagnetic radiation on oxidative stress parameters in eye tissue and blood of rats. Cutan .Ocul .Toxicol. ,Jun, 31(2).89-94. Epub 2012 Feb 16.

Dovrat, A., Berenson, R., Bormusov, E. \& Lahav, A. (2005). Localised effects of microwave radiation on the intact eye lens in culture conditions. Bioelectromagnetics, 26, 398-405. http://dx.doi.org/10.1002/bem.20114

Edward, M., Jennifer-Turner, H. \& Thomas, A. (1997). Sonic Hedgehog promotes rod photoreceptor differentiation in mammalian retinal cells in vitro. J. Neurosci., 17, 6277-6288.

Grigor'ev, I. G. (2003). Biological effects of mobile phone electromagnetic field on chick embryo (risk assessment using the mortality rate). Radiat. Biol. Radioecol, 43(5),541-543.

Hirata, A., Matsuyama, S. \& Shiozawa, T. (2000). Temperature rises in human eye exposed to EM waves in frequency range 0.6-6GHz. IEEE Trans. Electromagn. Compatibility, 42, 386-393. http://dx.doi.org/10.1109/15.902308

Hirata, A., Watanabe, H. \& Shiozawa, T. (2002). SAr and temperature increase in the human eye induced by obliquely incident plane wave. IEEE Trans. Electromagn. Compatibility, 44, 592-594. http://dx.doi.org/10.1109/TEMC.2002.804778

Hyland, G. J. (2000). Physics and biology of mobile telephony. The Lancet, 356, 1833-1836. http://dx.doi.org/10.1016/S0140-6736(00)03243-8

Inouye, M., Matsumoto, N., Galvin, M. J. \& McRee, D. I. (1982). Lack of effect of $2.45 \mathrm{GHz}$ microwave radiation on the development of preimplantation embryos of mice. Bioelectromagnetics, 3(2), 275-283. http://dx.doi.org/10.1002/bem.2250030211

Jensh, R. P. (1984). Studies of the teratogenic potential of exposure of rats to $6000 \mathrm{MHz}$ microwave radiation. I. Morphologic analysis at term. Radiat. Res., 97(2), 272-281. http://dx.doi.org/10.2307/3576279

Jensh, R. P., Weinberg, I. \& Brent, R. L. (1983). An evaluation of the teratogenic potential of protracted exposure of pregnant rats to $2450 \mathrm{MHz}$ microwave radiation: I. Morphologic 
analysis at term. J. Toxicol. Environ. Health, 11(1), 23-35. http://dx.doi.org/10.1080/15287398309530318

Kamimura, Y., Satio, K., Saiga, T. \& Amemiya, Y. (1994). Effect of 2045GHz microwave irradiation on monkey eyes. IEICE Trans. Commun. E 77-B, 762-765.

Kues, H. A., D'Anna, S. A., Oslander, R. \& Green, W. R. (1999). Absence of ocular effects after either single or repeated exposure to $10 \mathrm{~mW} / \mathrm{cm}^{2}$ from a $60 \mathrm{GHz} \mathrm{CW}$ source. Bioelectromagnetics, 20 , 463-473. http://dx.doi.org/10.1002/(SICI)1521-186X(199912)20:8<463::AID-BEM1>3.0.CO;2-T

Kues, H. A. \& Monahan, J. C. (1992) Microwave-induced changes to the primate eye. Johns Hopkins APL Technical Digest, 13, 244-255.

Kues, H. A., Monahan, J. C., D'Anna, S. A. \& McLeod, D. S. (1992). Increased sensivity of the non-human primate eye to microwave radiation following ophthalmic drug pretreatment. Bioelectromagnetics, 13, 379-393. http://dx.doi.org/10.1002/bem.2250130505

Lahijani, M. S. \& Ghafoori, M. (2000). Teratogenic effects of sinusoidal extremely low frequency electromagnetic fields on morphology of $24 \mathrm{hr}$ chick embryos. Indian, J. Exp. Biol., 38(7), 692-699.

Lary, J. M., Conover, D. L., Foley, E. D. \& Hanser, P. L. (1982). Teratogenic effects of 27.12 $\mathrm{MHz}$ radio-frequency radiation in rats. Teratology, 26(3), 299-309. http://dx.doi.org/10.1002/tera.1420260312

Lary, J. M., Conover, D. L. \& Johnson, P. H. (1983). Absence of embryotoxic effects from low-level (non thermal) exposure of rats to $100 \mathrm{MHz}$ radiofrequency-radiation. Scand. J. Work. Environ. Health, 9(2), 120-127. http://dx.doi.org/10.5271/sjweh.2434

Lindsay, C., James, K, L.,Emma, E, \& Mathew, D. (2004). Temporal \& saptial expression patterns of the CRX transcription factor and its down stream targets. Critical differences during human and mouse eye development. Am. J. Opthalmol., 191, 654-659.

Marcickiewicz, J., Chazan, B., Niemiec, T., Sokolska, G., Troszynski, M., Luczak, M. \& Szmiqielski, S. (1986). Microwave radiation enhances teratogenic effect of cytosine arabinoside in mice. Biol. Neonate., 50(2), 75-82. http://dx.doi.org/10.1159/000242571

Nakamura, H., Matsuzaki, I., Hatta, K., Nobukuni, Y., Kambayashi, Y. \& Ogino, K. (2003). Non thermal effects of mobile-phone frequency microwaves on uteroplacental functions in $\begin{array}{llll}\text { pregnant } \quad \text { rats. } & \text { Reprod. } & \text { Toxicol., } & \text { 17(3),321-326. }\end{array}$ http://dx.doi.org/10.1016/S0890-6238(03)00010-8

Nawrot, P. S., McRee, D. I. \& Staples, R. E. (1981). Effects of $2.45 \mathrm{GHz}$ cw microwave radiation on embryofetal development in mice. Teratology, 24(3), 303-314. http://dx.doi.org/10.1002/tera.1420240309

O'Conner, M. E. (1999). Intrauterine effects in animals exposed to radiofrequency and microwave fields.

Teratology,

59(4),

287-291. 


\section{Macrothink}

http://dx.doi.org/10.1002/(SICI)1096-9926(199904)59:4<287::AID-TERA13>3.0.CO;2-Y

Paulsson, L. E., Hamnerium, Y., Hansson, H. A. \& Sjostrand, J. (1979). Retinal damage experimentally induced by microwave radiation at $55 \mathrm{~mW} / \mathrm{cm}^{2}$. Acta. Ophthalmologica. 57, 183-197. http://dx.doi.org/10.1111/j.1755-3768.1979.tb00483.x

Sienkiewicz, Z. (1997). ABC of RF. Radiological Protection Bulletin, 196, 23-28.

Vignal, R., Crouzier, D., Dabouis, V., \& Debouzy, J. C. (2009) . Effects of mobile phones and radar radiofrequencies on the eye. Pathol. Biol .(Paris),Sep;57(6),503-8. Epub 2008 Nov 25.

Ye, J., Ya, K. \& Wu, R. (2001). Ultrastructural change of rabbit lens epithelial cells induced by low power level microwave radiation. Zhonghua. Yan. Ke. Za. Zhi., 37(1), 56-58.

Zareen, N., Khan, MY., Ali Minhas, L.(2009). Derangement of chick embryo retinal differentiation caused by radiofrequency electromagnetic fields. Congenit. Anom. (Kyoto), Mar, 49(1), 15-9.

Zusman, I., Yalfe, P., Pinus, H. \& Ornoy, A. (1990). Effects of pulsing electromagnetic fields on the prenatal and postnatal development in mice and rats: in vivo and in vitro studies. Teratology, 42, 157-170. http://dx.doi.org/10.1002/tera.1420420207

\section{Copyright Disclaimer}

Copyright reserved by the author(s).

This article is an open-access article distributed under the terms and conditions of the Creative Commons Attribution license (http://creativecommons.org/licenses/by/3.0/). 